\title{
The resultant physiochemical effect of organic, artificial and mixed diets of Clarias gariepinus to enhance growth
}

\author{
Solomon, R. J.* and Zainab, A. U. \\ Department of Biological Sciences, Faculty of Science, University of Abuja, Abuja, Nigeria. \\ ${ }^{*}$ Corresponding author. Email: johnsol2004@yahoo.com
}

Copyright $@ 2017$ Solomon and Zainab. This article remains permanently open access under the terms of the Creative Commons Attribution License 4.0, which permits unrestricted use, distribution, and reproduction in any medium, provided the original work is properly cited.

Received 30th April, 2017, Accepted 20th May, 2017

\begin{abstract}
This study was carried out at the University of Abuja permanent site Gwagwalada, Abuja to determine the water quality parameters of Clarias gariepinus fed with organic, artificial and mixture of organic and artificial diets. The materials and the fingerlings were all purchased from Ajima farms, Kuje Area Council. After seven days of acclimatization, a group of ten (10) fishes were stocked in three treatments of plastic rubber with carrying capacity of 60 litres. Treatment $A$ were fed with artificial (Coppens), treatment $B$ with organic (chicken droppings) while treatment $C$ with mixture of artificial and organic (both Coppens and chicken droppings) and the experiment ran for a period of 90 days. They were fed 7 days a week (twice daily) between 8 and 6 pm by hand casting at the rate of $4 \%$ body weight. The water quality parameters were taken once a week. Nitrate, $\mathrm{pH}$ and ammonia were calculated using combii 11 strip while temperature was taken using mercury in glass thermometer. The temperature was between $\left(26\right.$ to $\left.27^{\circ} \mathrm{C}\right), \mathrm{pH}(5$ to $8 \mathrm{mg} / \mathrm{l})$, nitrate $(0.01$ to $60 \mathrm{mg} / \mathrm{l})$, ammonia $(0.01$ to $2.15 \mathrm{mg} / \mathrm{l})$ and dissolved oxygen (5 to 6.6) respectively. All quality water parameters taken were found to be within the recommended range for optimum growth performance of Clarias gariepinus.
\end{abstract}

Key words: Artificial, organic (chicken droppings), combii 11 strip.

\section{INTRODUCTION}

Water is vital to the existence of all living organisms, but this value resources is increasingly being threatened as human population grow and demand more water of high quality for domestic purposes and economic activities. It is now generally accepted that aquatic as holding tanks that supply water for human activities. Rather these environments are complex materials that require careful use to sustainable ecosystem functioning well into the future.

Rivers are the most important freshwater resources for man, unfortunately disposal of sewerage, industrial waste and plethora of human activities which affects their physio-chemical characteristics and micro biological quality (koshy and Naya, 1999). Pollution of the aquatic environment is a serious and growing problem. Increasing numbers and amount of industrial agricultural and commercial chemicals discharged into the aquatic environment have led to various deleterious effects on aquatic organisms. Aquatic organisms including fish accumulate pollutants directly from contaminated water indirectly via the food chain (Hammer, 2004).

Owing to the large quantity of effluence discharged to the receiving waters, the natural processes of pathogen reduction are inadequate for protection of public health. In addition industries wastes that alter the water $\mathrm{PH}$ and provide excessive bacterial nutrients often compromise the ability of natural process to inactivate and destroy pathogens (Gerardi and Zimmerman, 2005). The extent of discharge of domestic and industrial effluents is such that rivers receiving untreated effluent cannot provide the dilution necessary for their survival as good quality water sources. The transfer of unfavorable release from industries is detrimental to human and animal health safety (Adekunle and Eniola, 2008). Disposal of sewage 
waste into a large volume of water could increase the biological oxygen demand (BOD) to such a high level that all the available oxygen may be removed, consequently causing the death of all aerobic species (Maduka, 2004). Prevention of river pollution requires effective monitoring of physics, chemical and micro-biological parameters (Chandra et al., 2006).

\section{African Catfish}

The African catfish Clarias gariepinus belongs to the family clariidae (Air-breathing Catfishes), order siluriformes (Catfishes), class actinopterygii (ray-finned fishes), sub-phylum vertebrata, phylum chordate and kingdom Animalia. The family clariidae is divided in to two genera viz: Clarias and Heterobrachus. There are over hundred species in this family occurring naturally throughput species in this family occurring naturally throughout most of Africa and the southern half the Java and the Philippines (Little et al., 1999). Clarias gariepinus is generally considered to be one is generally considered to be one of the most important tropical catfish species for aquaculture. It has an almost pan-African distribution, ranging from the mile to West Africa and from Algeria to southern Africa. They also occur in Asia minor (Israel, Syria and South of Turkey) (C. gariepinus) at various geographical locations bears different names. It is called C. lazera in northern and central Africa, (C. gariepinus) in South Africa (Vivean et, al. 1985). C. gariepinus is characterized with naked skin and elongate with fairly long dorsal and anal fins. The dorsal fin has 61-80 soft rays and the anal fin has $45-65$ soft rays. They have strong pectoral fin with spines that are serrated on the outer side (Taugels, 1986). In C. gariepinus, exchange of respiratory gas (i.e oxygen and carbon dioxide) takes place through the gills. Like any other mudfish, it has accessory breathing (arbores cent) organ which enables the fish not only to like in stagnant pools but to travel over damp ground (C. gariepinus differ from other catfishes in having an auxiliary breathing organ in this special pocket attached to the second and fourth gill arches and are responsible for the ability of (c. gariepinus) to live out of water much longer than other catfishes.

\section{Feed and feeding development}

Feed and feeding of catfishes in grow out ponds are perhaps the most documented in literature. Various efforts have been made to establish the crude protein and amino acid requirement of $C$. gariepinus (Ayinla and Akande, 1988 ) recommended $35 \%$ and $40 \%$ crude protein (CP) for raising table size and brood acid (EAA) required by warm water fish species only 3 EAAS studied have been documented and these are arginine, methionine and lysine. In order to formulate and compound aqua feeds that will meet the nutrient requirement of the catfish at affordable cost, several conventional and non- conventional animal by-product and plant residues have been tested to substitute or replace fish meal. Feeding development has moved from the use of single ingredient, broadcasting un-pelleted meal to pelleting and in fact the use of pelleted floating fish which has made a big difference to aquaculture development in Nigeria as C. gariepinus is being raised to maturity within 6 months (Ayinla and Akande, 1988).

\section{Conventional feed sources}

These are feed stud that are regularly used in the formulation of fish feed. Their usage is standardized and widely acceptable. Many of these are cheap and readily available in very large quantity. They are usually agroindustrial by products. Example include wheat bran, groundnut cake and rice bran, some are animal based (fish meal, blood meals, shrimp meal). Whereas others are plant based for example maize, soya bean meal, cotton seed meal. Generally these materials are relatively cheap and available throughout the year. However, Otubusin, (1992) pointed out that the effectiveness of a feed preferred is a determinant rather than cheapness. Hence balance is therefore needed, if aquaculture is profitable.

\section{Non-conventional feed stuff}

These are locally available feed stuff that is not standardized. The usage is not widely-spared and they are not consumed by man in most cases. Utilization in aqua-feed is very common especially in rural area of subSaharan African among low income group that are normally come from three sources. They include, kitchen wastes plant sources of feed and animal sources.

\section{Animal sources}

The non conventional feed stuff of animal origin are high quality feed ingredients that could compare to some extent with the conventional types. These are cheaper by virtue of the fact that there is no competition for human consumption. However, the only problem with these feed stuffs is their unavailability in large commercial quantities for the sustenance of aquaculture industries. In most part of Africa, these are available in small quantities and their production is inconsistent and sporadic in nature. Examples include tadpole meal, maggots earthworm meal, housefly larvae among others etc (Mohammed, 2009; Ugwumba, 2003; Ibiyo and Olowesegun, 2004).

\section{Plant source of feed}

These are generally known as non-conventional plant feed stuff (NCPF). These are in abundant, almost in every locality in Africa their potential and utilization in 
Table 1. Proximate composition analysis of feed ingredients.

\begin{tabular}{llllllllc}
\hline Ingredients & MO & CP & CF & CA & P & LS & MT & MR (Kcalg-1 $)$ \\
\hline Fish meal & 12.57 & 66.23 & 1.08 & 5.14 & 2.89 & 4.85 & 2.62 & 2861 \\
Groundnut Cake & 19.10 & 41.40 & 7.74 & 0.19 & 0.63 & 1.59 & 0.57 & 2892 \\
Blood meal & 15.12 & 76.20 & 1.46 & 0.29 & 0.09 & 6.90 & 1.00 & 3080 \\
Dried brewers grains & 12.89 & 18.60 & 20.00 & 0.20 & 0.16 & 0.81 & 0.98 & 1980 \\
White maize meal & 13.09 & 9.38 & 2.31 & 0.032 & 0.12 & 0.07 & 0.24 & 3434 \\
\hline
\end{tabular}

MO, moisture, CP, crude protein, CF, crude fibre, P, phosphorus, LS, lysine, MT, methionine + cysteine, ME, Metabolizable energy.

aqua culture fed have been reviewed (Ugwumb, 2003). Their levels of inclusion in aqua feed varies and largely depends on their availability nutrients level, processing technique, species of fish and cultural farming pattern prevalent in the locality (Mohammed, 2009).

The recommended level of inclusion of NCPF so many factors which limit higher level of incorporation and 305 of the diet. There are such as low protein content, amino acid imbalance and presence of ant nutritional factors (Alegbeleye et al., 2001).

\section{Kitchen wastes}

This is being used at household level of aqua culture especially in backyard fish farming where ruminants from house fold wastes are used to feed the fish, category are cassava peel was fed to tilapia. Recommended additional of $20 \%$ methonine with 205 inclusion of cassava peel also kitchen remnants like bread, cooked rice and yam are commonly used in the culture of fish (Alegbeleye et al., 2001).

\section{Aim of the study}

Fish farming is expanding rapidly throughout the world and has a high potential for the provision of valuable protein in less developed countries (Little and Edwards, 2003). Due to global population expansion, demand for high quality animal protein, especially from aquatic sources is rising. Increasing the aquaculture production is clearly needed to meet this demand in the third millennium, especially as the capture fisheries resources are declining due to over fishing, habitat destruction and pollution (Dunham et al., 2000). Hence, the study aim to analyze the physiochemical properties of the environmental conditions of the University of Abuja for Clarias gariepinus survival and growth.

\section{MATREIALS AND METHOD}

\section{Study area}

The study was carried out at the University of Abuja located at the Federal Capital Territory, Abuja. It is located along the Kaduna-Lokoja express road covering about 11,824 hectares. Abuja has an area of $1,043 \mathrm{~km}^{2}$ and a population of 157770 at the census of 2006 .

\section{Aquarium and treatment}

Thirty fingerlings of Clarias gariepinus were procured from Ajima farm in Kuje Area Council. These fingerlings were collected in an open plastic rubber with oxygenated water and were transported to the study area by car. After seven days of acclimation, a group of 10 fishes were stocked in three treatments of plastic rubber with carrying capacity of

60 L. Treatment A were fed with inorganic diet (Coppens), treatment B with organic (chicken droppings) while treatment $\mathrm{C}$ with mixture of inorganic and organic (both Coppen and chicken droppings). The experiment ran for a period of 90 days. They were fed seven days per week (twice daily at 8.00 am and $6 \mathrm{pm}$ ) by hand casting at the rate of $4 \%$ of their body weight.

\section{Biochemical composition of feed ingredients used in basal diet formulation}

Ingredients used in the formulation of diets (B) include: fishmeal, groundnut cake, blood meal, dried brewers grains and white maize meal (Table 1). The results of the analysis show that groundnuts cake had the highest $(19.10 \%)$ moisture content, while fish meal had the lowest $(12.57 \%)$. In terms of crude protein, blood meal had the highest $(76.20 \%)$ value while maize meal is recorded the lowest $(9.38 \%)$. The least of crude fibre is dried brewers grain with the value of $(20.00 \%)$ while the lowest $(1.08 \%)$ was recorded in fish meal. Fish meal had the highest $(5.14 \%)$ calcium contents while maize meal had the lowest $(0.03 \%)$.

\section{Nutrients compositions}

Nutrients composition of food ingredients was obtained from proximate ingredient as shown in (Table 1). The organic fertilizer was analyzed. Nutrients analyzed include: moisture (MO), Crude protein (CP), crude fibre 
(CF), calcium (CA), phosphorous (P), lysine (LS) and methionine + cystcine (MT). This was done according to the method of (AOAC 1999). Estimation of metabolizable energy (ME) of ingredient for the feed was calculated by converting the gross energy using the following equation as described by (Miller and Payne, 1959).

\section{Evaluation of fish performance}

Fish in each experimental tank were weighed every week to know the growth and health status of the fish and to adjust the feeding rate. Data obtained were for estimation of average weight gained (final weight-initial weight), mean length increment (final length-initial length), specific growth rate $(100 \times$ Ln final average weight - Ln initial average weight/days), Length-weight relationship was calculated using the convectional formulae for calculating the length-weight relationship.

$\mathrm{W}=\mathrm{aL}^{\mathrm{b}}$

The equation (1) and data were transformed into logarithm before the calculations were made therefore equation (1) becomes:

$\log W=\log a+b \log I$

Where, $\mathrm{W}=$ weight of the fish $(\mathrm{g}), \mathrm{L}=$ standard length of the fish $(\mathrm{cm}), \mathrm{a}=$ constant and $\mathrm{b}=$ an exponent

\section{Condition factor}

The condition factor " $k$ " was also calculated for individual fish for each month using the conventional formulae (Worthington and Richard, 1930).

$\mathrm{K}=\mathrm{W} \times 100 / \mathrm{L}^{3}$

Where, $\mathrm{K}=$ condition factor, $\mathrm{W}=$ weight $(\mathrm{g})$ and $\mathrm{L}=$ standard length $(\mathrm{cm})$

\section{Water quality analysis}

Water quality parameters of the experimental tanks was analyzed at every 7 days during the period of study for the minimum and maximum temperature, Ammonia, $\mathrm{pH}$, dissolved oxygen and Nitrate thermometer, ammonia, $\mathrm{pH}$, Nitrate and dissolve oxygen were determined using combi II (test strip). Data generated from the experimental analyze variance (ANOVA) which was carried out to test the variation of the water quality parameters. These were found to be within acceptable limit for fish growth and health. Phosphorus was very high $(2.89 \%)$ in fish meal and very low $(0.09 \%)$ in blood meal. The highest (4.85 and $2.62 \%)$ lysine and methionine values were observed in fishmeal while lowest $(0.27$ and $0.24 \%)$ were seen in white maize feed
Table 2. Composition of organic fertilizer and formulated feed used in 90 days in tank $a, b$, and $c$.

\begin{tabular}{lccc}
\hline Ingredients & Tank A & Tank B & Tank C \\
\hline Organic fertilizer & - & 50.00 & 50 \\
Coppens & 50.00 & - & 50 \\
Salt & 0.25 & 0.25 & 0.25 \\
Fish meal & 4.00 & 4.00 & 4.00 \\
Groundnut cake & 12.90 & 12.90 & 12.90 \\
Blood meal & 6.00 & 6.00 & 6.00 \\
Dried brewers grain & 12.95 & 12.95 & 12.95 \\
White maize meal & 14.90 & 14.90 & 14.90 \\
\hline
\end{tabular}

Table 3. Nutrient composition, organic, formulated feeds, and coppens used in the culture of Clarias gariepinus for 90days.

\begin{tabular}{lccc}
\hline Nutrients & Organic fertilizer & Basal diet & Coppens \\
\hline Dry matter & 92.30 & 90.88 & 90.092 \\
ME & 3126.00 & 3102.16 & 3045.30 \\
Methionine & 1.66 & 0.70 & 0.893 \\
Lysine & 2.83 & 1.93 & 1.866 \\
Phosphorus & 0.80 & 0.47 & 0.827 \\
Calcium & 0.74 & 0.52 & 1.110 \\
Lipids & 15.10 & 7.01 & 12.50 \\
Crude fibre & 2.35 & 6.30 & 2.18 \\
Crude Protein & 39.00 & 35.00 & 44.00 \\
\hline
\end{tabular}

respectively. Metabolizable energy was very high (3434 Kcal kg-1) in white maize meal and lowest $(1980 \mathrm{kcal} \mathrm{Kg}$ $\left.{ }^{1}\right)$ values was recorded in dried breweries grains (Tables 2 and 3).

\section{Production parameters}

The list weight gained and the highest from week 0 to 12 in Tank $A, B$ and $C$ were 0 to 14.02 , the least and the highest length gained in all the Tanks $A, B$ and $C$ from weeks 0 to 12 were 0 to 6.8 and the survival rate were 80 to 100 respectively which shows that not only the feed but the water parameters were within the acceptable rate for the growth and survival rate of the fish.

\section{RESULTS AND DISCUSSION}

Water quality parameters are one of the major importance factors in aquaculture production the water quality parameters such as temperature, $\mathrm{pH}$, Nitrate, Ammonia and dissolved oxygen were determined during the study period. The abnormal concentration of any of these water quality parameters may have been the cause of the fish death. However numeration and density stress are additional parameters for fish death. The temperature 
Table 4. Summary of water quality parameters for Tank A.

\begin{tabular}{llll}
\hline Parameters & Sum & Average & Range \\
\hline Temp $\left({ }^{\circ} \mathrm{C}\right)$ & 345 & 26.53846 & 1.00 \\
$\mathrm{pH}(\mathrm{mg} / \mathrm{l})$ & 79.8 & 6.13846 & 5.00 \\
Ammonia $(\mathrm{mg} / \mathrm{l})$ & 17.11 & 1.31615 & 1.82 \\
Nitrate $(\mathrm{mg} / \mathrm{l})$ & 150.14 & 11.5923 & 5.90 \\
Dissolved acid & 79.8 & 6.13846 & 5.00 \\
\hline
\end{tabular}

Table 5. Summary of water quality parameters for Tank B

\begin{tabular}{llll}
\hline Parameter & Sum & Average & Range \\
\hline Temp ${ }^{\circ} \mathrm{C}$ & 344 & 26.4615 & 1.00 \\
$\mathrm{pH}(\mathrm{mg} / \mathrm{l})$ & 103.60 & 7.92308 & 1.10 \\
Ammonia (mg/l) & 6.05 & 0.46538 & 1.57 \\
Nitrate $(\mathrm{mg} / \mathrm{l})$ & 150.12 & 11.54769 & 59.90 \\
Dissolved acid & 79.9 & 6.14615 & 5.0 \\
\hline
\end{tabular}

Table 6. Summary of water quality parameters for Tank C.

\begin{tabular}{llll}
\hline Parameter & Sum & Average & Range \\
\hline Temp ${ }^{\circ} \mathrm{C}$ & 346 & 26.61538 & 1.00 \\
$\mathrm{pH}(\mathrm{mg} / \mathrm{l})$ & 104 & 8 & 0.80 \\
Ammonia $(\mathrm{mg} / \mathrm{l})$ & 16.63 & 1.279231 & 1.82 \\
Nitrate $(\mathrm{mg} / \mathrm{l})$ & 150.13 & 11.54846 & 59.90 \\
Dissolved acid & 76.6 & 6.046154 & 1.00 \\
\hline
\end{tabular}

recorded during the study period ranged between $26^{\circ} \mathrm{C}$ to $27^{\circ} \mathrm{C}$ respectively. The temperature reading in all the experiment (Tank A, B and C) were within a permissible range. These shows that the readings are within a required or tolerable range for the culture of fish for optimum fish performance. The mean hydrogen $10 \mathrm{~m}$ $(\mathrm{pH})$ concentration recorded for the treatments, ranged from between $7.0 \mathrm{mg} / \mathrm{L}$ to $8.5 \mathrm{mg} / \mathrm{L}$. This shows that the acidity of the experimental water were in the range that supported the survival of the fishes into the experimental tanks and fall within the recommended $\mathrm{pH}$ range of 6.5 $\mathrm{mg} / \mathrm{L}$ to $85 \mathrm{mg} / \mathrm{L}$ for good performance. The concentration of Ammonia in the experimental water was low. Tank $A$ has a mean ammonia level of $1.36 \mathrm{mg} / \mathrm{L}$, Tank B $0.45 \mathrm{mg} / \mathrm{l}$ and Tank $C 1.20 \mathrm{mg} / \mathrm{L}$ respectively. The low level of Ammonia concentration in the experimental water could be due to the low level of biomas. The low level of oxygen may be due to metabolic activities of the fishes and of bacteria decaying organic material such as underutilized feel. The mean value of dissolved oxygen of the experimental water was found to be between $5.5 \mathrm{mg}$ to $6.6 \mathrm{mg} / \mathrm{L}$. The ranges of the dissolved oxygen of the experimental water remain within acceptable limits (Huet, 1972). In the early week of the study, Nitrate was high but gradually lowed as the growths of the fishes were achieved in all the experiment. The average values of Nitrate in the experimental water, $11.55 \mathrm{mg} / \mathrm{L}$ for tank $\mathrm{A}, 11.54 \mathrm{mg} / \mathrm{L}$ for tank $B$ and 11.54 $\mathrm{mg} / \mathrm{L}$ for tank $C$ respectively may have adequately supported the growth of the fishes (Tables 4, 5 and 6 and Figures 1, 2 and 3).

\section{Conclusion}

The result of this study shows that Tank $A$ and $C$ has moderate values of all the physiochemical parameters studied compared to Tank B perhaps this could be the reason why the fishes in Tank $A$ and $C$ did well than those in than B. Generally, all water quality parameters studied were found to be within the recommended ranges for optimum performances of Clarias gariepinus. This indicates that the environmental conditions of the permanent site of the University of Abuja may offer condusive conditions for not only Clarias gariepinus survival and growth but for other fishes. 


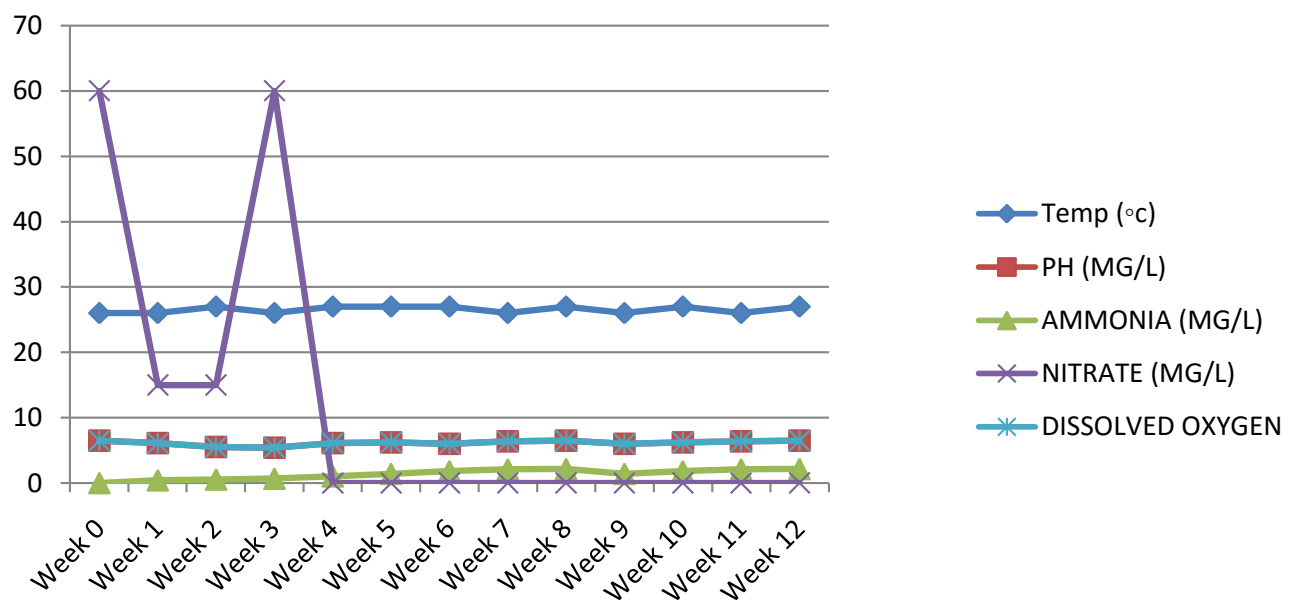

Figure 1. Chart for Water Quality parameters for Tank A (Inorganic diet).

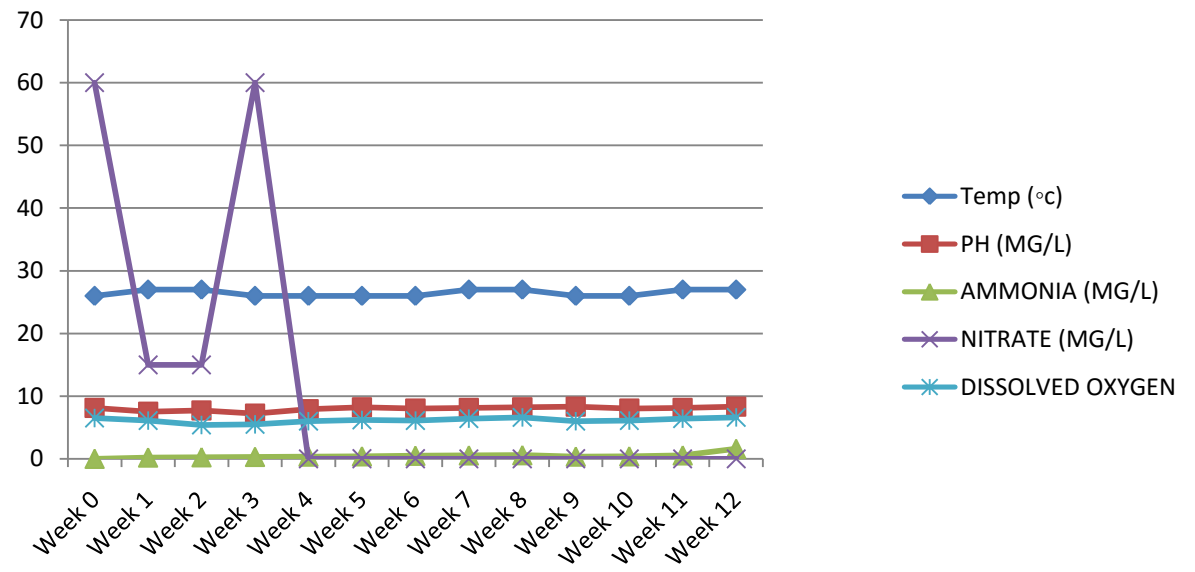

Figure 2. Chart for Water quality parameters for Tank B (organic diet).

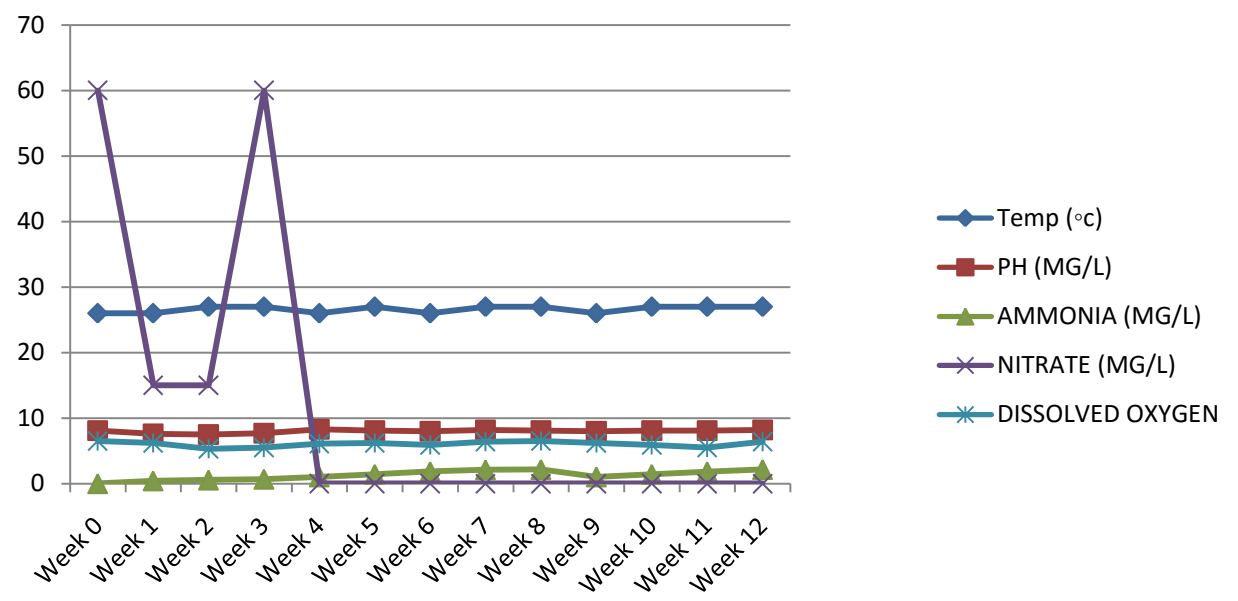

Figure 3. Chart for water quality parameters for Tank $\mathrm{C}$ (organic and inorganic diet). 


\section{CONFLICT OF INTEREST}

The authors declare that they have no conflict of interest.

\section{REFERENCES}

Adekunle, A. S., \& Eniola, I. T. K. (2008). Impact of industrial effluents on quality of segment of Asa River within an industrial estate in Ilorin, Nigeria. New York Science Journal, 1(1), 17-21.

Alegbeleye W.O, Oresegun A, \& Ayintomi (2001). An assignment of Jackbean (Canavalisensiformis) meals an ingredient in the diets for clarias gariepinus fingerlings fish nutrition and fishfeed technology in Nigeria. Processing of the First National symposium on fish nutrition and fish feed Technology. Lagos. Pp. 89-94

Ayinla, O. A., \& Akande, G. R. (1988). Growth response of Clarias gariepinus on silage based diets. Nigeria Institute of Oceanography and Marine Research. Technical Paper, 62, 15.

Chandra, R., Singh, S., \& Raj, A. (2006). Seasonal bacteriological analysis of Gola river water contaminated with pulp paper mill waste in Uttaranchal, India. Environmental monitoring and assessment, 118(1), 393-406.

Dunham, R. A., Majumdar, K., Hallerman, E., Bartley, D., Mair, G., Hulata, G., Pongthana, N, Bakos, J, Penman, D., \& Gupta, M. (2000). Review of the status of aquaculture genetics. In Aquaculture in the Third Millennium. Technical Proceedings of the Conference on Aquaculture in the Third Millennium, Bangkok, Thailand Pp. 137-166.

Gerardi, M. H, \& Zimmerman M.C (2005) Waste Water Pathogens. John Wiley and sons Inc; Hobaken NJ, USA: Pp. 3-4.

Hammer, M. J. (2004). Water and waste water Technology. $5^{\text {th }}$ Edition Practice Hall Inc; Upper Saddle River, NJ USA, Pp. 139-141.

Huet, M. (1972). Textbook of fish culture, breeding and cultivation of fish. Fishing News (books) Ltd. England. p. 33.
Ibiyo, L. M. O., \& Olowosegun, T. (2004). The potential for improving profitability in aquaculture pp. 45-53. In processing of the $19^{\text {th }}$ Annual conference of the fisheries society of Nigeria (FISON) llorin, p. 896.

Koshy, M., Naya, T. V. (1999). Water quality aspects of rivers Pamba. Pollution Research, B 501-510.

Little, D. C., \& Edwards, P. (2003). Integrated livestock-fish farming systems. Inland water resources and aquaculture service. Animal production service. FAO, Rome.

Little, D. C., \& Muir, J. F., \& Price, R. (1999). Fish farming in tropical fresh water. Stoas Box 78m 6700 AB Wageningen, Netherlands. p. 64

Maduka, H. C. C. (2004). Water pollution and Man's health in environment Degradation, Reclamation conservation and pollution control for the rural women and the youths. Greenline publisher, Ado Ekiti, Nigeria, Pp. 198-203

Miller, D. S., \& Payne, P. R. (1959). Aballistic bomb calorinmeter. British Journal of Nutritious, B501-508.

Mohammed, F. A. S. (2009). Histopathological studies on Tilapia zilli and Solea vulgaris from lake Quran, Egypt. World J. Fish Mar. Sci, 1, 29-39.

Otubusin S. O. (1992). Aquaculture food security and environment invented. Lecture presented at the formal launching at the National Association of fisheries students (NAFIS). University of Agriculture, Abeokuta (UNAAB).

Taugels, G. (1986). A Systematic revision of the Africa species of the genus clarias (pisces cllaridae). Annual Muse Royal del' Afrique centrate, Pp. 247-199.

Ugwumba, A. O. (2003). Aquaculture options and the future of fish supply in Nigeria. The zoologist, 2, 96-122.

Viveen, W. J. A. R., Richter, C. J. J., Van Oordt, P. G. W. J., Janssen, J. A. L., \& Huisman, E. A. (2013). Practical manual for the culture of the African catfish (Clarias gariepinus). 